\title{
Domestic Tourism in Indonesia: Another Story of Inequality between Java and Non-Java
}

\author{
Wini Widiastuti ${ }^{*}$ \\ BPS-Statistics of Nusa Tenggara Barat Province, Mataram, Indonesia
}

\begin{abstract}
This study aimed to examine the pattern of movement of domestic tourists within one country, in this case, in Indonesia. Although many scholars had been addressed by tourism in their research, both international and domestic tourism, there was a limited study that examined the spatial pattern of domestic tourism, especially in developing countries. Therefore, this study intended to do so.This study employed a descriptive analysis of the new data set gathered from the Study of Domestic Tourism Market 2017. The result of this study showed that, although visitors can travel either inside one province or to many other provinces in Indonesia, however, the majority of visitors prefer to travel within one province, which might be related to several factors such as cost and transportation facilities. The data also showed evidence of inequality, especially when comparing Java and Non-Java Provinces. One of the reasons for those disparities can be explained by the fact that people living in Java tend to travel only to other provinces around Java Islands. Another reason is that the level of economic development differs from Java and the outer islands. Transportation access has also affected the disparities since all provinces in Java get benefited from the sophisticated and interconnected transportation systems. On the contrary, NonJava Provinces are hindered by the limited access to transportation modes or by the expensive transportation cost. A big difference in the average income per capita between Java and Non-Java residents also contributed to the inequality in the number of tourists among the provinces. The individual with high income, of course, has more opportunity to do traveling to many places and to visit attractive sites.
\end{abstract}

Keywords: developing country, domestic tourism, economic development, regional disparities.

\section{INTRODUCTION}

The positive impact of the tourism sector on economic development has been widely recognized by many scholars [1]. Early findings by Pearce in 1981 classified the impact of tourism for the national economy closely related to balance of payment, regional development, and diversification of the economy, income levels, state revenue, and employment opportunities [2].

Foreign tourism allows the flow of money into the national economy that positively influences the country's trade balance and the government account [3]. Countries then could utilize the additional receipt from abroad to fund their national projects. As concerning regional development, tourism industries also establish in the peripheral area, sometimes remote, hence helps to advance and to spread the economic activities across the national boundary. Furthermore, tourism triggers diversification of the economy since there are lots of sectors involve in fulfilling the needs of visitors such as accommodation, transportation, restaurants, and tourist attractions.

Tourism positively influences not only tertiary sectors but also primary and secondary sectors [4]. When tourists buy the product of the tertiary

\footnotetext{
* Correspondence address: Wini Widiastuti

E-mail : wini.widiastuti@gmail.com

Address : BPS-Statistics of Nusa Tenggara Barat Province, Mataram
}

sector, it then increases the demand for raw or intermediate materials needed to manufacture such a product. For example, if many tourists ordered fried rice at a restaurant, then the demand for fried rice will increase. In order to fulfill the increase of consumer demand on fried rice, the restaurant will have to order more rice from supplier, which means there will be an increase in demand of rice as well.

Based on the origin of visitors, there are two types of tourist i.e. international tourists and domestic tourists. Some argue that international visitors could give high benefits to the economy because it is related to the inflow of foreign money. Inbound tourists from overseas could benefit the national economy through the inflow of money spent by foreign visitors while traveling. It can be pre-paid, during, or after the traveling take place. Aggregation of spending money by foreign tourists gives positive impact on the trade balance and government accounts [3]. Although the initial receipt could be lower for the fee that flows to foreign tour operators and for the cost of the foreign campaign, Pearce explained tourism allows the inflow of foreign currencies [2].

However, domestic tourism is also important because it can give more sustainable socioeconomic development in a region. Moreover, the money of domestic tourists will stay within the country, instead of flowing out of the country by traveling abroad. 
Although domestic tourism only utilizing the existing national economic resources, the impact of domestic tourism on national development is also as important as international tourism. First, countries with a high number of inhabitants provide an abundant supply of potential domestic visitors. Second, domestic tourism is arguably more sustainable than international tourism. Unlike international visitors that required submitting special permits prior to their traveling journey, the country's residents can travel around as they wish. Moreover, international tourism also subject to political tension, for example, travel warning issued by origin countries could prevent potential foreign visitors to come. In fact, travel advice has a negative impact on inbound tourism [5].

Third, it is true that on average spending by domestic visitors usually lower compared to international visitors. However, domestic visitors spend more than international tourists. The previous study found similar expenditure behavior and linkages between international and domestic tourists in Melaka [6]. They also noted the differences between those two types of tourists. The first type of tourist spends more money on luxurious accommodation, food, and beverages compared to the latter. It might be related to the length of stay as well as preferences. Therefore, the local economy could gain more comprehensive economic benefits by promoting both types of tourism.

Fourth, Zaei [7] argued that by encouraging domestic tourism could lead to strengthening national integration. The research stresses the importance of domestic tourism in Indonesia since the country put national integration as the objective of national development. Although many touristic places in one country usually offer quite similar amenities such as natural and cultural attractions, one place might have slightly differed from the others. Moreover, cultural attraction between provinces are different, even there is also apparent cultural differences within one province. Such differences could trigger people to visit another place.

Given the intriguing advantage of tourism, a lot of countries set tourism as a leading sector of their economic policy. It is not limited to developed countries but also developing countries, including Indonesia. Based on the Medium-Term Development Plan 2015-2019 [8], Indonesian tourism industry also labeled as one of the country's leading sectors. Unfortunately, many countries heavily based their tourism policy in favor of international visitors, while domestic visitors still underrepresented [9]. The action that they need to do is to promote both international and domestic visitors equally [10].

Although previous research attempts to study domestic tourism, especially in developing countries, is abundant, there have been only a few studies that include the spatial matter in their analysis. Therefore, this study aims to examine the pattern movement of domestic tourist within one country, in this case, in Indonesia.

\section{MATERIAL AND METHOD}

This study employed a descriptive analysis of domestic tourism data at the provincial level in Indonesia. All provinces included in the analysis, including North Kalimantan, the newest province in the country. The data were retrieved from the result of the Study of Domestic Tourism Market 2017 conducted by the Ministry of Tourism and BPS-Statistics of Indonesia. Besides the total number of travelers from each province, the data also disaggregated into two types of domestic tourists, who travels within the province and the other one who travels between provinces in Indonesia. Therefore, the study examined three types of domestic tourists, which are total, within the province, and between provinces.

Apart from that, this study also analyzes differences in domestic tourism between Java and Non-Java. The first-category includes provinces located in Java Island, which are Jakarta, West Java, Banten, Central Java, Yogyakarta, and East Java. Meanwhile, the second-category includes provinces located outside Java Island namely Aceh, North Sumatera, West Sumatera, Riau, Jambi, South Sumatera, Bengkulu, Lampung, Bangka Belitung Islands, Riau Islands, Bali, West Nusa Tenggara, East Nusa Tenggara, West Kalimantan, Central Kalimantan, South Kalimantan, East Kalimantan, North Kalimantan, North Sulawesi, Central Sulawesi, North-East Sulawesi, Gorontalo, West Sulawesi, Maluku, North Maluku, West Papua, and Papua.

\section{RESULT AND DISCUSSION}

Indonesia's domestic tourists travel inside their province as well as to other provinces. In 2017, the number of domestic tourists reached 270,82 million travelers. Most of them trip within a province, with the percentage slightly above $70 \%$, while the other $30 \%$ travel to places located in another province (Fig. 1). It suggests that travelers prefer to travel inside a province compared to outside the province. 


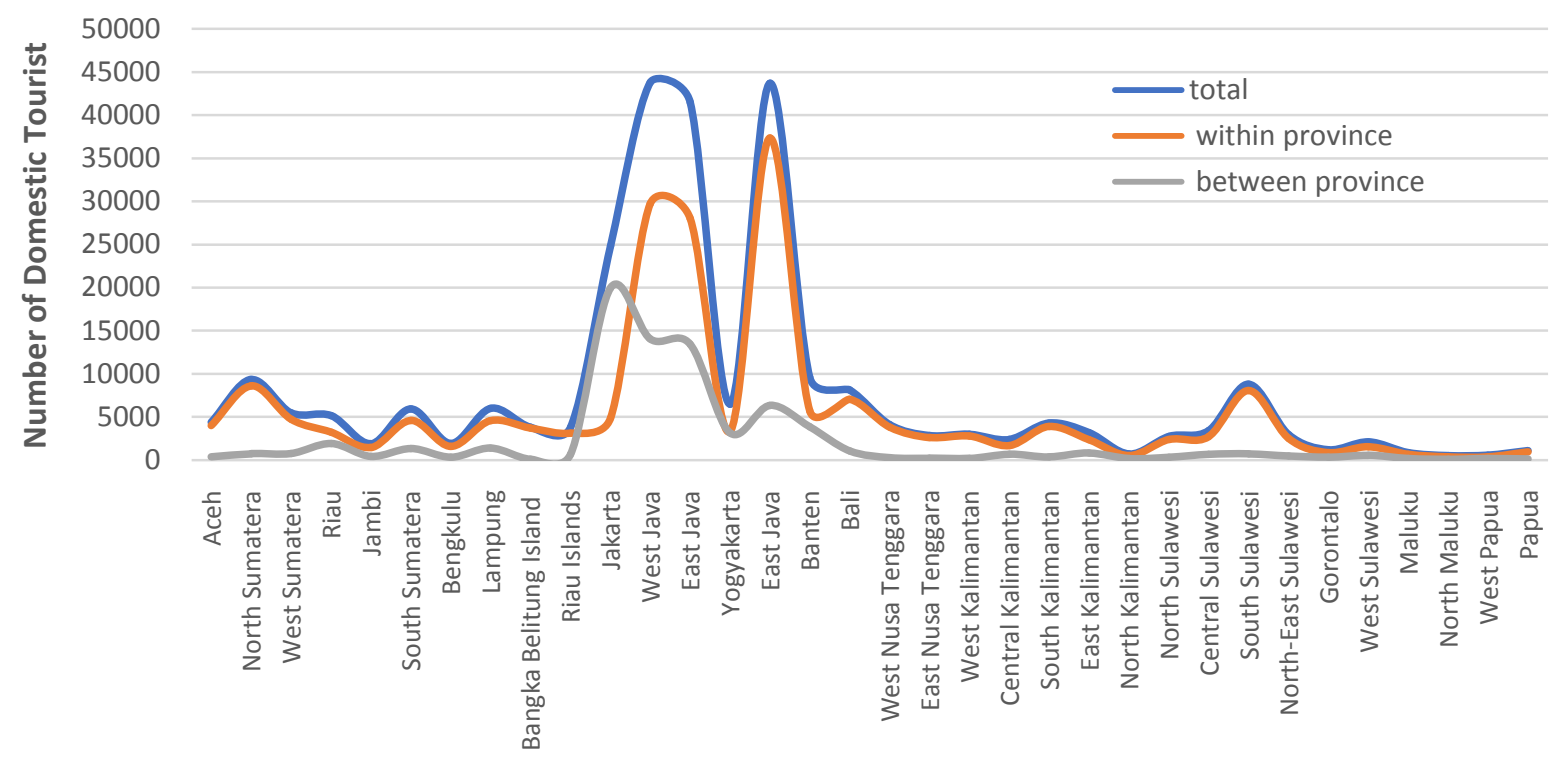

Province

Figure 1. The Number of Domestic Tourists by Province, 2017

Source: Author's own calculation based on Study of Domestic Tourism Market, 2017.

Table 1. The Results of Descriptive Statistics of Domestic Tourism using SPSS

\begin{tabular}{lllllll}
\hline & N & Minimum & Maximum & Sum & Mean & Std. Deviation \\
\hline total & 34 & 513.206 & 43779.162 & 270822.003 & 7965.35303 & 11884.768737 \\
inside & 34 & 388.448 & 37340.064 & 194141.133 & 5710.03332 & 8543.591249 \\
outside & 34 & 107.969 & 19971.680 & 76680.870 & 2255.31971 & 4552.447271 \\
\hline Valid N (listwise) & $\mathbf{3 4}$ & & & & & \\
\hline
\end{tabular}

Source: Author's own calculation based on Study of Domestic Tourism Market, 2017.

Looking at the regional pattern, the majority of domestic travelers were coming from West Java as many as 43.78 million tourists, followed closely by East Java, with only less than 9 thousand travelers at 43.69 million tourists. Meanwhile, the smallest number of domestic tourists come from the eastern part of the country, which is North Maluku and West Papua, with 0.51 million tourists and 0.58 million tourists, respectively. In other words, there is evidence of a high gap in the number of domestic tourists among provinces in Indonesia.

The trend also persistent when examining domestic tourists based on their destination, whether they conducted the trip inside or outside one province. The differences between provinces were considerably high for both types of tourists. As can be seen ain Table 1, for the first type of traveling, the maximum number reached 37.34 million travelers, and the minimum number documented at 0.39 million travelers. As for the latter, the maximum number reached 19.97 million travelers and the minimum number only 0.11 million travelers.

Which province position at the top and the bottom of the rank, however, differs from the aggregate. Figure 1 showed that the highest number of tourists traveling within their province observed in East Java, and the lowest number has occurred in North Maluku. Meanwhile, the highest number of travelers visiting another province is coming from Jakarta, and the lowest number is coming from Bangka Belitung Islands.

Even though Java only consists of six provinces, the vast majority of domestic tourists are from Java, which was $62.7 \%$, while the rest of the 28 provinces were shared, the remaining $37.3 \%$. This feature (not surprising), since almost all Java provinces except for Yogyakarta, has a high number of domestic tourists that are above the national average (7.96 million). Meanwhile, only three out of twenty-eight Non-Java provinces surpass the national average, namely North Sumatera, South Sulawesi, and Bali. Moreover, only $15.7 \%$ of domestic tourists from non-java province travel to another province. It is far below the percentage of domestic tourists from java travel to another province that is $35.8 \%$.

The matrix in Table 2 demonstrated that when they travel to the area outside their province, Java's domestic tourists mostly travel to another province around Java Island. The percentage was quite remarkable, which is $90 \%$ or 54.7 million travelers. In which West Java, Central Java, and Yogyakarta are among the most favorable 
destination. Meanwhile, the rest of $10 \%$ or 10.1 million travelers visit places outside Java. Meanwhile, Provinces such as Bali, Lampung, and North Sumatera are the most visited province by Java's domestic tourists.

Table 2. Matrix of Domestic Tourism that Travel Between Province in Indonesia, 2017

\begin{tabular}{|c|c|c|c|}
\hline \multirow{2}{*}{ Source } & \multicolumn{2}{|c|}{ Destination } & \multirow{2}{*}{ Top 10 Destination } \\
\hline & Java & Non-Java & \\
\hline (1) & (2) & (3) & (4) \\
\hline Java & 89.9 & 10.1 & $\begin{array}{ll}\text { 1. } & \text { West Java } \\
\text { 2. } & \text { Central Java } \\
\text { 3. Yogyakarta } \\
\text { 4. Jakarta } \\
\text { 5. East Java } \\
\text { 6. Banten } \\
\text { 7. Bali } \\
\text { 8. Lampung } \\
\text { 9. } \\
\text { 10. } & \text { North Sumatera } \\
\end{array}$ \\
\hline $\begin{array}{l}\text { Non- } \\
\text { Java }\end{array}$ & 35.3 & 64.7 & $\begin{array}{ll}\text { 1. } & \text { Jakarta } \\
\text { 2. } & \text { East Java } \\
\text { 3. } & \text { South Sulawesi } \\
\text { 4. } & \text { North Sumatera } \\
\text { 5. } & \text { West Sumatera } \\
\text { 6. } & \text { Riau } \\
\text { 7. } & \text { Central Java } \\
\text { 8. } & \text { West Java } \\
\text { 9. } & \text { South Kalimantan } \\
\text { 10. } & \text { Bengkulu }\end{array}$ \\
\hline
\end{tabular}

Source: Author's own calculation based on Study of Domestic Tourism Market, 2017

The behavior of Non-Java's domestic tourists was different from Java's domestic tourists. Instead of traveling amongst Non-Java province, the top two destinations are Java provinces, which were DKI Jakarta and East Java. In total, $35.3 \%$ of Non-Java's domestic tourists go to Java, while the majority of $64.7 \%$ visited Non-Java's province.

Disparities of domestic tourists among Java and Non-Java provinces might be related to several reasons. First is the availability of sophisticated and well-connected transportation infrastructure in Java. Moreover, the type of transportation also varied, such as planes, cars, as well as trains. It gives a wide range of options to choose from for potential travelers. Valek [11] suggested that the expenditure level could varied based on mode of transportation as well as time of traveling. The variety of transportation also influences the cost of traveling. Therefore, the one who traveling not only those who have high disposable income but also those who have moderate disposable income since they could choose cheaper mode of transportation.

Meanwhile, transportation infrastructures in Non-Java Provinces are less developed not only in terms of connection but also the variation of a mode of transportation. Some provinces, especially island provinces, are connected to another province by limited transport facilities, which is also costly such as plane. If they choose to travel using a cheaper mode of transportation, it takes a lot of time to reach the destination province. The abundant and cheap mode transport that available in Java pulls the potential domestic tourists to visit another province. Meanwhile, the limited and (sometimes) expensive mode of transportation in Non-Java provinces, hinders domestic tourists to visit other provinces

Second, income inequality between Java and Non-Java provinces also plays important role in shaping the pattern of domestic tourism in Indonesia. Tourism activity is often seen as a leisure activity, in which one would pursue their passion for traveling if they already fulfill their basic needs. Less income household tend to spend their income on food and other important needs than on tourism and other leisure-related activities [12]. Therefore, tourism behavior is closely related to the income of an individual or household. The higher the income, the higher is the probability of individual or household to travel. Based on monthly expenditure per capita, the average expenditure per capita of Java is $16 \%$ higher than of Non-Java. Therefore, Java residents are more likely to conduct trips within their province as well as between provinces.

Third, the number of inhabitants in Java was slightly higher compared to Non-Java Provinces. In $2017,57 \%$ of Indonesian population lived in Java, while the remaining $43 \%$ lived outside Java. It could be seen as the supply of potential domestic tourists in Java was also higher.

\section{CONCLUSION}

Tourism, as the engine of growth and the booster of economic development, has been widely recognized. Many countries, including Indonesia, set the tourism sector as a center of their economic policies.

The result showed that tourists travel either inside a province or travel to many other provinces in Indonesia. However, the majority of tourists prefer to travel only within one province. The data showed that there was an inequality in the number of domestic tourists among the provinces. Some provinces have a high number of tourists, while others have lesser. The data also showed evidence that the disparities in the number of domestic tourists were very prominent, especially when comparing Java and Non-Java Provinces.

One of the reasons for those disparities was explained by the fact that people living in Java tend to travel only to other provinces around Java Island. Another reason was due to the fact that the 
level of economic development differs from one province to another. Transportation access has also affected the disparities since all provinces in Java benefited from the sophisticated and interconnected transportation systems.

On the contrary, Non-Java Provinces are hindered by the limited access to transportation modes or by the expensive transportation cost. A big difference in the average income per capita between Java and Non-Java residents also contributes to the inequality in the number of tourists among the provinces. The individual with high income, of course, has more opportunity to do traveling to many places and to visit attractive sites.

In conclusion, to optimally utilize the potential of domestic tourism in Indonesia, this study recommends both the central and local governments to promote not only tourist destinationz in Java but also outside Java. It is also important to provide a cost-effective and interconnected transportation system among provinces between Java Island and other Islands. These policies could boost the number of domestic travelers visiting Non-Java provinces, which in turn also reduces inequality not only in terms of tourism but also in economic development. Along with traveling, domestic tourists were also transferring wealth from Java to other Provinces.

\section{REFERENCES}

[1]. Bayramoğlu, T. and Y. O. Ari. 201. The relationship between tourism and economic growth in Greece Economy: a time series analysis, computational methods in social sciences 3(1), 89-93.

[2]. Giaoutzi, M. and P. Nijkamp. 2017. Amazing trends in tourism development in an open world. In: Giaotzi,M. and P. Nijkamp (Eds). Tourism and Regional Development: New Pathways. Routledge. London.

[3]. Sugiyarto, G., A. Blake, and M. T. Sinclair. 2003. Tourism and globalization. Economic impact in Indonesia. Annals of Tourism Research 30(3), 683-701.

[4]. Rusu, S. 2011. Tourism multiplier effect. Journal of Economic and Business Research 1, 70-76.

[5]. Mylonopoulos, D., P. Moira, and A. Kikilia. The travel advice as an inhibiting factor of tourist movement. TIMS Acta 10, 13-26.

[6]. Amir, S, M. M. Osman, S. Bachok, and M. Ibrahim. 2015. Understanding domestic and international tourists' expenditure pattern in Melaka, Malaysia: result of CHAID analysis. Procedia-Social and Behavioural Science 172, 390-397.
[7]. Zaei, M. E. 2013. The impacts of tourism industry on host community. European Journal of Tourism and Research 1(2), 12-21.

[8]. Ministry of National Developmet Planning (Bappenas). 2014. Rencana Pembangunan Jangka Panjang Menengah Nasional (RPJMN) 2015-2019. Bappenas. Jakarta.

[9]. Rogerson, C. M. and Z. Lisa. 2005. 'Sho't Left': Changing Domestic Tourism in South Africa. Urban Forum 16(2-3), 88-111.

[10]. Kabote, F. and P. W. Mamimine. 2017. Domestic tourism for sustainable development in developing countries. African Journal of Hospitality, Tourism and Leisure 6(2), 1-12.

[11]. Valek, N. S. 2015. Tourism expenditure according to mode of transportation: A comparative study between 2009 and 2012 . Journal of Tourism, Heritage and Services Marketing 1(1), 3-9.

[12]. Sheyhaki. M. H. 2014. Happiness, leisure and tourism vs household budget in Iran. Asia Pacific Journal of Multidiciplinary Research 2(3), 103-110. 